\title{
Policing of Goods Piracy in a Developing Country: A Case of South Africa
}

\author{
Godfrey Thenga \\ University of South Africa, Pretoria, SOUTH AFRICA \\ College of Law, Department of Police Practice
}

Received: 2 March 2020 • Accepted: 30 May 2020 • Published Online: 12 June 2020

\begin{abstract}
South Africa forms part of the global village and is not exempted from goods piracy. These substandard goods pose physical and health risks to consumers and business. This study explored the policing of goods piracy in South Africa and the abilities of law enforcement agencies to police this crime. A qualitative research design was adopted. A literature review and interviews were conducted to provide an overview of this problem. The involvement of organized criminals exacerbates the problem and indications are that corruption is rampant in law enforcement agencies. Law enforcement agencies working in silos result in the rapid spreading of goods piracy. A shortage of skilled police members and a lack of training are identified as major problems. The findings of this study can serve as guidelines for preventative and reactive response mechanisms and can suggest ways of improving efficiency and effectiveness in policing goods piracy.
\end{abstract}

Keywords: policing of goods piracy, South Africa, corruption, copyright infringement, work, money laundering.

\section{Introduction}

South Africa is a dumping ground for pirated goods. It will cost the country a great deal of money to dispose of them safely (South African Institute of Intellectual Property Law, 2015). The streets and shops in the country's biggest cities are inundated with traders who, on a daily basis, sell pirated goods to knowing and unsuspecting consumers despite the fact that trading in pirated goods is a copyright infringement and an Intellectual Property crime. Goods piracy is a crime that needs to be policed in South Africa. It is the duty of law enforcement officials in every country to enforce the law and prevent crime. In South Africa, the South African Police Services (SAPS) is responsible for policing crime that occurs within the borders of the country.

A major problem in the policing of goods piracy is the fact that the manufacturers of pirated goods are located in several countries across the world. The manufacturers and dealers form part of organised criminal groupings and, to make matters worse, they make use of unregulated and hazardous materials in producing pirated goods. Pirated goods are copied from original goods without the permission of the original goods owner and resemble the genuine goods (Beauchamp, 1998: 278). The Copyright Act, 98 of 1978, criminalises trading in pirated goods. In terms of Section 2 of the Copyright Act, the following categories of works, if they are original, are eligible for copyright protection: literary and artistic works, cinematography, signals, published editions and computer programs.

(C) Authors. Terms and conditions of Creative Commons Attribution 4.0 International (CC BY 4.0) apply. Correspondence: Dr Godfrey Thenga (Senior lecturer), University of South Africa, College of Law, Department of Police Practice, Pretoria, SOUTH AFRICA. E-mail: tshabg@unisa.ac.za. 
Unlike the original goods, pirated goods have not been tested by authoritative institutions to determine if the materials used in producing them are not harmful to people. With the advent of advanced technological machinery and tools, the manufacturers of pirated goods have perfected their skills to such an extent that it becomes difficult, if not impossible, for an ordinary consumer to distinguish between genuine and pirated goods without carrying out tests (Bain \& Veloutsou, 2007: 212). As a result, criminals continue to sell pirated goods in streets and shops to consumers in many countries, including South Africa.

Intellectual property crime is a consumer fraud that hampers innovation and creativity in all nations (Spilsbury, 2009: 4). Section 41 (4) of the South African Copyright Act stipulates that no copyright shall subsist otherwise than by virtue of the Copyright Act. Goods that are protected by intellectual property rights enjoy a monopoly conferred by the state to prevent unauthorised production and exploitation by unscrupulous people (Staake \& Fleisch, 2008: 33).

Consumer fraud is the hijacking of another person's product of the mind, the criminal production of goods that resemble that of the lawful owner, and the selling of the goods purported to be what they are not, with the ultimate goal of making an exorbitant profit (Treadwell, 2011: 176). Criminals who pirate goods that are owned by other people earn an unlawful income because they had not spent money on conducting research, developing the goods and procuring quality materials. A study conducted by BASCAP (2009: i) on the dangers and extent of pirated goods revealed the grievous losses that goods piracy causes governments and the lawful owners of genuine goods.

Despite a considerable body of literature on the dangers that goods piracy poses to people and the environment both nationally and internationally, no research study was conducted on the policing of goods piracy in South Africa.

It is against this background that the article will highlight the extent of goods piracy in South Africa and the issues which complicate the policing of goods piracy. Furthermore, this study will suggest guidelines for the policing of goods piracy.

\section{Policing function}

The policing function involves the prevention and detection of crime and the maintenance of law and order in society. This task is carried out by law enforcement officials such as the police (Newburn, 2008: 17). The police are expected to deter or prevent the occurrence of specific crimes, first, by altering the environment in which they occur; secondly, by changing the conditions which are thought to cause them; and, thirdly, by providing a strong deterrent in the form of an effective criminal justice system (White Paper on Safety and Security, 1999: 14). Policing involves crime prevention and any actions designed to reduce the level of crime and/or the perceived level of fear of crime with the intention of serving justice. In this context, the policing function is operationalised as the prevention and/or investigation of goods piracy.

The police is granted powers by the state to enforce the law. Section 205(3) of the Constitution of the Republic of South Africa, 108 of 1996, holds the SAPS responsible for protecting people and property, and maintaining law and order (South Africa, 1996a). The police also have a legislative mandate to serve society in terms of Section 13 of the South African Police Service Act, 68 of 1995.

\subsection{Specialized Commercial Crime Unit}

The Specialised Commercial Crime Unit is a division of the SAPS that is responsible for investigating commercial crimes. The Unit has branches in strategic provinces in South Africa 
and investigates commercial crimes above R100 ooo. The Unit has dedicated members who are trained to police goods piracy in the country. Unfortunately, many capable members left the Specialised Commercial Crime Unit and joined private organisations and the corporate sector. The loss of manpower and financial crime investigation skills resulted in a skills and staff shortage. This has corroborated the assertion of some crime researchers that the SAPS is struggling to fight commercial crime (Corruption Watch, 2012). The skills and manpower shortage experienced by the Specialised Crime Unit has allowed crime to spiral out of control. Sensitive cases that are not speedily resolved could send a wrong signal to potential criminals of the police's inability to police commercial crimes such as goods piracy (Burger, 2014: 1). Poorly trained members could also burden the SAPS with litigation problems because they inevitably violate peoples' rights in the discharge of their duties. For instance, in the 2014/2015 financial year the pending civil claims against the SAPS stood at over R26 billion owing to the violation of peoples' constitutional rights (Deveymaeker, 2015: 29). Litigation is often caused by a lack of police professionalism and poor compliance with the laws and relevant policies of the SAPS.

\section{Goods piracy}

Goods piracy infringes property rights. In South Africa the 1996 Constitution protects property rights. Section 25 of the Constitution makes it a criminal offence to violate individual property rights. Copyrights are unregistered rights that allow copyright owners to prevent the unauthorised reproduction of their goods. The fact that the owners of genuine goods do not have to register as legitimate owners does not justify the reproduction of their products without their permission. Their ownership is automatically protected by the state. Piracy is an enormous problem globally. Business Software Alliance claims that $98 \%$ of the software used in China, including that used by the Chinese government, are illegal copies (Beauchamp, 1998: 278). China is regarded as the capital of copyright crimes. The cost-benefit analysis gives a better explanation of the economic benefits of goods piracy (Pires, Schneider \& Herrera, 2016: 5). Criminals engage in criminal activities that are intended to reward them financially and this principle seems to hold in goods piracy. SAFACT (2009: 2) alleges that criminals use airports to bring pirated goods to South Africa.

\subsection{The extent and magnitude of goods piracy globally}

Goods piracy figures stand at around $6 \%$ to $10 \%$ of all trade globally and indicates that the industry is projected to be making more than $\$ 600$ billion annually (Lewis, 2009: 47). The above figure was for 2008 and the numbers have since increased with global trade uptake. In 2009 the United Nations (UN) reported that goods piracy constituted $7 \%$ of the world trade, an equivalent of 600 billion US dollars a year globally. This report further indicated that industries such as the computer software industry, and online streaming are lucrative markets for criminal syndicates that also produce drugs and illegal substances (Basu \& Lee, 2015: 39).

The OECD (1998: 30) indicates that 67\% of the world's pirated goods originate from China. It causes South African businesses an annual loss of over R2 billion in imported goods. These include a loss in sales, goodwill and royalties, among others (South African Institute of Intellectual Property Law, 2013: 16). The majority of criminals run the goods piracy business supply chain in a way similar to that of a legitimate business with undesirable consequences. The fact that some of the legitimate business owners mingle their genuine products with pirated goods, is unfair to legitimate producers and owners of goods (Joyce, 2011: 76).

The 2008 data of the value of illicit trade shows that the total global economic value of pirated products was 650 billion US dollars annually. South Africa, as a developing nation, is also included in the figures. According to ICC (2010), the impact of pirated goods would exceed 1.77 
trillion US dollars with a possibility of more than 2.5 million people being placed out of work and not being able to earn a livelihood. No country in the world is unaffected by the problem; only the degree in which they experience it varies.

\section{International property crime}

Intellectual property crime is a crime of the mind. It could be divided into industrial property such as patents, trademarks, industrial designs, geographical indications and copyright that covers literary, films, music, artistic, architectural designs as well as recordings (WIPO, 2014: 2). Sonmez (2014: 758) asserts that goods piracy is an attractive business for free riders. Kerns (2016: 573) equates it with the capturing of another person's ideas by developing and imitating products without incurring a significant investment, thereby eroding the competitive edge of the original product owner.

\subsection{Organised crime}

Organised crime thrives when money is involved. Goods piracy is the most common commercial crime that terrorists engage in to finance their activities (Beare, 2012: 77). In South Africa, international criminals have been operational even before the democratic dispensation. They pose a serious security threat to the country (Govender, 2012: 1). Members of organised crime are a specialised subset of a criminal enterprise who maintain their position through the use of violence and blackmail. Businesses that are run by organised criminals are well resourced and sustainable (Spink, Meyer, Park \& Heinonem, 2013: 60). The danger of organised criminals operating businesses is that they mingle the goods with pirated goods and have small armies that are responsible for squashing opposition. Legitimate businesses that are profitable are extorted and owners are threatened to pay bribes as a protection fee. Criminal bosses use sophisticated means, have significant financial resources, and are domiciled across the globe (Spink et al., 2013: $60)$. Many of them own properties in various countries.

Organised criminals are able to rope in countries' government officials to overcome administrative hurdles, access privileged government information, and are tipped off by the authorities if they were reported for the violation of laws (Balsamo, 2006: 373-377). This behaviour by government officials is tantamount to sharing confidential and protected information with criminals (Payne, 2013: 66). This conduct is unethical as privileged information is given out to the public in exchange of payment (Adejumo, 2010: 2). In terms of Section 1 of the Prevention of Organised Crime Act, 121 of 1998, police officials who have legitimate access to and control of sensitive information yield to corruption if they exchange it with criminals. As a consequence, governments are often unable to fight organised crime.

\subsection{Money laundering}

According to Le Khac, Markos, O’Neill, Brabazon, and Kechadi (2011: 504), money laundering is the third largest business in the world. Its turnover is estimated at between 500 billion and 1 trillion US dollars annually. Money from criminal activities is laundered to disguise its origin and elevate it to a legitimate status. Money laundering makes crime a worthwhile endeavour for criminals (Mackrell, 1996:47, South Africa, 1996b: 13). According to Choo and Smith (2008: 45) and Financial Action Task Team Guidance (2013a: 28), these criminals:

- use agents and mules to open bank accounts for them where transaction will be made to launder the money, and/or 
- use their intermediaries, family and close associates to launder the dirty money on their behalf and they pay them a service fee or bribe.

Goods piracy is a consumer fraud and is, according to the police in South Africa, perpetrated by mostly organised criminal gangs with links with the Chinese Triad from Hong Kong and Taiwan such as the $14 \mathrm{~K}$ and the Wo Shing Wo (Gastrow, 1999: 62). The above assertion confirms the prevalence of organised crime that dates back before the democratic dispensation in South Africa. Organised criminals are aware that they are wanted by the police and attempt to evade justice through devious means such as hiding the proceeds of crime and source of money when transacting.

South Africa is a member of the FATF, an organisation which sets international standards to combat money laundering and terrorism around the world (Tuba, 2012: 103). All member countries are required to conclude international agreements to combat transnational crimes such as terrorism and organised crime.

\subsection{International legislative framework regulating goods piracy}

Articles 6 and 7 of the United Nation's Convention Against Transnational Organised Crimes, also referred to as the Palermo Convention, make money laundering a criminal offence deserving of sanction. Another convention that makes money laundering punishable is the United Nations Convention Against Illicit Traffic in Narcotic Drugs and Psychotopic Substances, which was adopted in 1998. This Convention criminalises illicit trafficking, which could also be interpreted as the trafficking of money and drugs, and encourages governments to confiscate blood money and the proceeds of crime.

\section{Context of study}

The study was conducted in South Africa, which is a developing country characterised by high levels of crime. Developing and underdeveloped countries are a target for the dumping of goods and for goods piracy.

\section{Methodology}

\subsection{Study population and procedure}

A qualitative approach and empirical design were followed in this study. Miles, Huberman and Saldana (2014: 11) describe it as a study that covers an array of interpretive techniques and seeks to describe, decode and translate information to get the meaning of a naturally occurring phenomenon in the social world. The design was appropriate for this study as there was little information in literature that could achieve the objective of this study, namely proper policing of goods piracy which involves preventative and reactive mechanisms.

The researcher used this design to obtain credible data from respondents and the observation of raids. A video recorder was used in seven raids that were conducted in various places to record the conduct of police and suspects during searches and the seizure of pirated goods. A recording was made of the people who were unaware that they were observed. Data was also gathered through individual face-to-face semi-structured interviews. The information was based on the police's involvement in activities to curb, reduce or eradicate goods piracy. The researcher asked operational people how goods piracy was policed, who assisted in the policing of goods piracy and what the extent of goods piracy was. The questions were directed at SAPS members, prosecutors from the National Prosecuting Authority (NPA), Department of Trade and 
Industry (DTI) officials, owners and/or authors of goods or products, and attorneys. The members of the SAPS comprised of ten Specialised Commercial Crime Unit investigators and 66 members who conducted crime prevention duties. The other groups are seven prosecutors, five brand holders, four DTI officials and five Attorneys. A sample of 97 participants were selected in order to explore the policing of goods piracy in South Africa by various stakeholders responsible for combatting goods piracy. The researcher conducted fieldwork during an eight-month period extending from March 2018 to October 2018. The study commenced after the SAPS, NPA and DTI had granted permission to conduct research. Various provinces (Gauteng, Mpumalanga, the Western Cape and KwaZulu-Natal) were visited and interviews were conducted with the participants.

The sample was purposively selected because the researcher knew people who had the information and knowledge to assist in the research. A voice recorder and filed field notes were used to supplement information gathering.

\subsection{Data analysis}

The collected data from interviews and the observation data were transcribed to facilitate the process. It was analysed methodically according to the thematic method by classification into themes, sub-themes and categories. To this effect, Tesch's eight-step data analysis method, as discussed in Creswell (2014: 198), was used. It involved getting a sense of the whole; picking one of the transcribed interviews and reading it carefully; making a list of topics and clustering them; coding and classifying information; making a final decision and alphabetising the codes; assembling same categories; doing a preliminary analysis; and, finally, recording the data.

\subsection{Ethical considerations}

An ethical clearance was obtained from the College of Law at the University of South Africa before the commencement of this study (Ethical clearance reference number P29 issued on 23/09/2015). In this study, the researcher ensured confidentiality by not disclosing the personal details of the participants. The researcher obtained informed consent from all 97 participants in this study. The participants consented to be interviewed and were not coerced to partake in the study; hence participation was voluntary. All participants were informed that they were permitted to withdraw from the interviews. Participants were not allowed to discuss their individual responses among themselves. The information they provided was kept in a safe place. Participants were not remunerated for participating in the interviews. Video recordings of the raids were made with the consent of the SAPS management.

\section{Findings and discussion}

This section of the study laid emphasis on the analysis, presentation and interpretation of data that were collated in the course of this study. The interviews and observations results produced the themes and sub-themes. Statements by participants were confirmed by the observations. Four main questions and several sub-questions were posed in semi-structured interviews with 76 participants. The participants included SAPS members, prosecutors of the NPA, officials of the DTI, owners and/or authors of goods or products, and attorneys. The members of the SAPS included ten Specialised Commercial Crime Unit investigators and 66 members responsible for crime prevention. The other groups were seven prosecutors, five brand holders, four officials of the DTI, and five attorneys. A total of 97 people took part in this study. The responses of 97 interviews that were obtained by asking participants about their own 
understanding of how goods piracy is policed in South Africa. This resulted in the following themes and sub-themes.

\subsection{The nature and extent of goods piracy in the world and in South Africa}

The findings indicate that goods piracy is a growing industry in the world and there are no signs that this phenomenon will subside in the near future. The statistics indicate that $60 \%$ of the total number of articles seized in the world in 2018 originated from China (Chaudhry \& Zimmerman, 2013: 12) and that some legitimate businesses in South Africa are also guilty of goods piracy. Some legitimate-goods owners stated that the fight against goods piracy is undermined by the lack of a collaborative effort among production houses since legitimate producers operate in secrecy in an attempt to protect their products against copying. This is exacerbated by the fact that the use of protective items on goods means higher costs for producers.

A member of the Specialised Commercial Crime Unit confirmed this by stating that: "China is destroying innovation in the world and legitimate producers of goods operate on a limited budget to invest in protecting their genuine goods so that it does not push up prices for genuine goods too high."

Most respondents stated that piracy goods are often produced in large quantities and sold at a lower price than that of genuine goods. This explains why consumers are eager to buy them. Piracy goods have a huge target market, namely the youth. Young people buy them at train stations, taxi ranks, bus terminals, shopping complexes, and flea markets across South Africa. Most of the sellers are foreign nationals and many of them are undocumented immigrants. Some of the more sophisticated sellers advertise and sell their goods online.

Almost all members of the Specialised Commercial Crime Unit, crime prevention units and the DTI mentioned that porous borders make it easy to bring pirated goods in the country. Bribery of corrupt law enforcement officials is another factor that enables goods piracy to thrive. Pirated goods that are taken from one country to another complicates the effective and efficient policing of this crime. Illicit goods are transported by air and sea. Goods piracy is a relatively easy enterprise and the considerable returns that it generates makes this crime attractive for terrorists and organised criminals who facilitate money laundering.

Criminals import plain goods, labels and machines to the country in separate consignments. Here they assemble the machines and reproduce goods that mimic the original. These are sold not only in South Africa but also in neighbouring countries. In contrast with police in countries such as the USA and Britain, the South African police do not make use of intelligence in their policing of goods piracy, and sporadic raids are seldom launched on sellers and dealers.

\subsection{Policing of goods piracy}

Members of the Specialised Commercial Crime Units, Crime Prevention Units and the DTI indicated that traders of goods piracy do not fear the police since some police members take bribes and abdicate their responsibility to confiscate pirated goods and or arrest the traders. However, in areas where the relationship between the police and community is good, the police receive information about criminal activities from community members. Here the fight against this crime tends to be more successful.

A member of the Specialised Commercial Crime Unit substantiated this by stating that: "Many police members accept bribes from traders and this causes the police to lose respect from both the community and traders. As a consequence, community members hesitate to report crime and traders do not show respect for the police as they have them in their purse". 
Many countries do not regard this crime as a top priority that needs concerted policing. Most of them, including South Africa, do not punish the buying of pirated goods for private use. This means that only the sellers are prosecuted. In many African countries it is common that criminals in possession of a few pirated goods for household use are not prosecuted.

A member of the Specialised Commercial Crime Unit vindicated this by stating that "It is not a crime to carry few pirated goods for household use as long as one is not selling to the public, and this makes policing difficult as people would use household use as a defence when they are arrested".

Organised criminals are active in the goods piracy business as they consider it less risky. People who are arrested for this crime tend to be represented by reputable legal representatives and, if they are convicted, most of them prefer paying a fine to serving a jail term. A Crime Prevention Unit member corroborated this by stating that "Even the presiding officers do not impose sentences that are proportional to crimes committed".

Countries such as Finland, New Zealand, Sweden, Norway, Italy, France, and the USA, have stronger laws against goods piracy and impose harsher sentences on dealers and sellers (Levy-Carciente, 2016: 16). It is difficult to identify and arrest the leaders of organised crime as they live all over the world, and produce sufficient evidence to arrest and convict them. The challenge of finalising extradition arrangements between countries is also an impeding factor because not all countries are willing to enter into such agreements. Moreover, the leaders or organised crime syndicates use other people to sell their consignments in various countries.

In South Africa, the owners who lease stalls and business premises to traders who sell these goods are seldom arrested and charged for partaking in criminal activities. Most of the selling areas are unmarked stalls and spaces. Because a fixed physical address is a precondition for the granting of warrants of search and seizure, it is difficult for the police to act. Market stalls that are not properly marked could lead to a search and seizure operation at the wrong stall, which could expose the police to litigation.

During an interview, one respondent stated: "Property owners rent out properties, structures and spaces to criminals who trade in illicit goods and are never arrested for partaking and promoting criminality which is bad."

The other complication in South Africa is that most pirated goods sellers are economic migrants who sell illegal goods on the streets to make a living. What compounds this problem is the fact that many street vendors do not pay for a rental space and that many economic migrants use piracy goods as an opportunity to earn an income. They target places such as taxi and bus ranks, shopping complexes, open streets, streets opposite shops, trains and train stations, cinemas, major events and other entertainment sites.

South Africa lacks a coordinated system to keep statistics of goods piracy across the three major government departments that are involved in policing goods piracy, which are the DTI, Customs and Excise and the police. Uncoordinated ICT among these Departments impedes progress in the war against pirated goods. Against that, some dealers use sophisticated technology to communicate and transact with their fellow perpetrators. Proper use of integrated technology by these government departments is essential for the effective and efficient policing of this crime by law enforcement agencies.

\subsection{Factors that hamper effective policing of goods piracy in South Africa}

Various factors impede the effective and efficient policing of goods piracy in South Africa. This indicates the complex nature of dealing with this challenge which requires a multipronged and integrated strategy. 


\subsection{Prosecution of goods piracy}

Few prosecutors at the Specialised Commercial Crime Courts in the nine provinces are trained to prosecute piracy goods criminals. Prosecutors working in courts other than Specialised Commercial Crime Courts such as magisterial and high courts, are neither trained. Therefore, they do not have the specialised skills required for prosecuting piracy goods criminals.

One prosecutor affirmed: "Goods piracy should not be treated as a specialised matter; every prosecutor should be trained to prosecute these cases in any court."

\subsection{Corruption within the police and other law enforcement agencies}

Corruption in the ports of entry fuels criminality. Customs and excise officials and the police allow illicit substances and pirated goods into the country (Meltzer, 2010: 46). Pirated goods that have already entered the country are sold on the streets, in flea markets and at transport terminals. Police members do not confiscate them, but allow criminals sell them to the public in return for a bribe. Dedicated police members receive threats from organised criminals who are hand in glove with corrupt police members. As a result, the lives of honest police members and their families are in constant danger.

One of the police members confirmed this by revealing that: "Many police members are organised criminals themselves. Some law enforcement members are very corrupt and many communities do not trust the police."

Some groups of organised criminals have links with the SAPS top management, who tip them off about impending raids (or searches and seizures). Members of the Specialised Commercial Crime Unit stated that, sometimes, police members at ports of entry are instructed by senior officers of the police and Customs and Excise not to search specific individuals' goods and consignments. Some organised crime leaders pay senior officers bribes in exchange for protection.

Almost all members of the Specialised Commercial Crime Unit claimed that law enforcement agencies are infiltrated by national and international criminals.

\subsection{Characteristics of goods piracy}

Since some pirated goods resemble the genuine product, it is difficult, if not impossible, to identify them at a glance. Dealers of pirated goods re-invest most of their profits in goods manufacturing equipment. This high-tech equipment makes spotting pirated goods almost impossible. Because confiscated products need to be tested, many legitimate producers based in other countries send their testers (equipment) to South Africa to conduct tests.

One Crime Prevention Unit member corroborated this by stating that: "The naked eye cannot see what are piracy goods and what are not. It is difficult to distinguish pirated goods from originals without proper training."

Some legitimate goods owners outsource the production of their goods to external producers who, in most cases, produce it in excessive numbers to earn a higher income. This is unethical as the producers are not the owners of the goods.

\subsection{Testing of pirated goods}

To have a justiciable case, the court needs scientific reports confirming that goods are piracy goods. Owing to the shortage of experts in the country, goods have to be sent to foreign 
countries for testing so that cases can be brought before the courts. Every producer of goods has its own testers. Unfortunately, they are not constantly in the country.

The testing of goods is conducted by the legitimate goods owner's representatives at the legitimate goods owner's expense. Because testing is not conducted by a neutral institution, the results could be biased. During an interview, one respondent stated: "The Copyright Act grants the legitimate owner of goods the position of both player and referee of the game. This seems suspect. The complainants are the ones who test the alleged pirated goods and issue reports that confirm or dispute goods piracy".

\subsection{Police powers}

There is no sign of the proactive policing of goods piracy. The police mostly wait for complaints from owners who report goods piracy. Legitimate owners of goods employ legal representatives who test and evaluate the purchased alleged pirated goods. Proof of offending goods such as purchase receipts, copies or images are needed before a case can be reported to the police. One Specialised Commercial Crime Unit member declared: "The owners of goods hire attorneys who have no knowledge of investigation work to do test purchases at suspicious shops and stalls, instead of forensic investigators who are experienced in investigation work."

\subsection{Shortage of manpower in the Specialized Commercial Crime Unit}

There is shortage of workers with critical skills in the Specialised Commercial Crime Unit owing to natural attrition and members leaving this unit in droves for appointments in the private sector. This affects the capacity of the Unit to deal with goods piracy crime. This was confirmed by the then Acting Head of the Directorate for Priority Crime Investigation, MajorGeneral Yolisa Matakata, when she briefed the Portfolio Committee on Police on 16 February 2018.

One Specialised Commercial Crime Unit member said: "Skilled commercial crime police members are absorbed by corporates. They leave the SAPS for better perks and working conditions."

An analysis of the staff complement of this Unit as part of research conducted from 2014 to 2018 confirms this. The head of the Directorate for Priority Crime Investigations, General Godfrey Lebeya, also regarded the shortage of skills and lack of competence of members as an impediment to winning the commercial crime war.

One respondent from the Specialised Commercial Crime Unit was asked about measures that were put in place to tackle manpower shortage and lack of critical skills in the Unit. The respondent declared that "The Specialised Commercial Crime Unit is a skeleton without any flesh, because if someone leaves the service, there is no replacement".

\subsection{The strategy used to police goods piracy}

Neither the SAPS nor the DTI has a strategy for dealing with goods piracy criminals. Even the Specialised Commercial Crime Unit does not have strategy to police goods piracy. The SAPS, the DTI and the Specialised Commercial Crime Unit follow a generic strategy referred to as the National Crime Prevention Strategy to fight crime including goods piracy. There is not even an in-house policy on how goods piracy crime should be policed.

Almost all groups of members alluded to the lack of a goods piracy strategy across all law enforcement agencies. 


\section{Conclusion}

The article explored the policing of goods piracy. It presented the empirical and literature findings for enhancing the policing of goods piracy and improving cooperation between law enforcement agencies and communities in the fight against this crime.

Goods piracy trade has undesirable consequences for people, business and government. The involvement of organised crime groupings in goods piracy trade is responsible for the upsurge in the crime and money laundering. It is apparent that the policing of goods piracy is an enormous task that cannot be successfully achieved or accomplished by the SAPS alone. The involvement of other law enforcement stakeholders such as Customs and Excise and the DTI, is critical. The failure of proactive policing is evident from the presence of pirated goods in the markets, and requires reactive policing to arrest perpetrators and deter potential criminals. The successful prosecution of perpetrators serves as both proactive and reactive crime prevention activities that leads to deterrence.

There is a need to determine how organised criminals are able to force law enforcement officials and politicians to kowtow to them. The emphasis of this study was on proactive activities to protect owners' private property rights in terms of the South African Constitution. Corruption in the SAPS frustrates the fight against goods piracy. Victimisation of the police can be eradicated by adopting proactive approaches to policing. These have to involve intelligence and surveillance in policing, and an active society that works in conjunction with the police and other stakeholders. Proper policing of this crime could discourage perpetrators from committing this crime.

This study could assist the SAPS in policing goods piracy crime. Other law enforcement stakeholders such as Customs and Excise and the DTI, could also benefit from it. It can assist them in customising the guidelines for use in policing goods piracy in their sphere of operation. If law enforcement agencies continue to work in silos, they will fail in the fight against goods piracy.

\section{Acknowledgements}

This research did not receive any specific grant from funding agencies in the public commercial, or not-for-profit sectors.

The author declares no competing interests.

\section{References}

Adejumo, A. O. (2010). Relationship between psycho-demographic factors and civil servants' attitudes to corruption in Osun State, Nigeria. Internet Journal of Criminology, 1, 2-3.

Agnew, R. (1992). Foundation for a general strain: Theory of crime and delinquency. Criminology, 3o(1), 47-88.

AIC (2003). Crime reduction matters. Canberra: Australian Government Printer.

Balsamo, A. (2006). Organised crime today: The evolution of the Sicilian mafia. Journal of Money Laundering, 9(4), 373-378.

BASCAP (2011). Estimating the global economic and social impacts of counterfeiting and piracy. London: Frontier Economics. 
BASCAP (2009). The impact of counterfeiting on government and consumers. London: Frontier Economics.

Basu, M. M. \& Lee, Y. (2015). Factors affecting intention to buy counterfeit products. Marketing Management Association. Springs 2015 Proceedings: 39-47.

Beare, M. E. (2012). Encyclopaedia of transnational crime and justice. Los Angeles: Sage.

Beauchamp, E. R. (1998). Dimensions of contemporary Japan: A collection of essays. New York: Garland.

Berg, J., \& Shearing, C. (2011). The practice of crime prevention: Design principles for more effective security governance. South African Crime Quarterly, 36, 23-30.

Bian, X., \& Veloutsou, C. (2007). Consumers' attitudes regarding non-deceptive counterfeit brands in the UK and China. Journal of Brand Management, 14, 211-222.

Burger, J. (2014). The SAPS must renew its focus on specialised units. Available from http://www.defenceweb.co.za/index.php?option=comcontent\&view=article\&id $=34221$ :issthe-south-african-police-service-must-renew-its-focus-on-specialise: d-units \& catid=3:Civil\%20 Security. Accessed: 2019/03/26.

Chaudhry, P., \& Zimmerman, A. (2013). The global growth of counterfeit trade. New York: Springer Science.

Choo, K. K. R., \& Smith, R. G. (2008). Criminal exploitation of online systems by organized crime groups. Canberra: Springer. Asian Criminology, 3, 37-59.

Clarke, R. V. (1997). Situational Crime Prevention: Successful Case Studies. $2^{\text {nd }}$ edition. New York: Harrow and Heston.

Cohen, L. E., \& Felson, M. (1979). Social change and crime rate trends: A routine activity approach. American Sociological Review, 44, 588-608.

Corruption Watch (2012). National crime statistics don't help corruption fight. Available from Corruptionwatch.org.za.content/national-crime-stats/help-corruption-fight. Accessed: 2019/03/26.

Creswell, J. W. (2014). Research design: Qualitative, quantitative, and mixed methods approaches. $4^{\text {th }}$ edition. Los Angeles: Sage.

Deveymaeker, G. (2015). Making sense of the numbers: Civil claims against the SAPS. South African Crime Quarterly, 54, 29-41.

Financial Action Task Team Guidance (2013). Money laundering and terrorist financing through trade in diamonds. Paris: Edmont group of financial intelligence units.

Forst, B. (2009). Terrorism, crime, and public policy. New York: Cambridge.

Gastrow, P. (1999). Main trends in the development of South Africa's organised crime. African Security Review, 5(6), 58-69.

Govender, D. (2012). Reflections on the strategic leadership in the South African Police Service on violent crimes and policing. Acta Criminologica: Southern African Journal of Criminology. CRIMSA 2011 Conference Special Edition (2): 1-16.

ICC (2010). Intellectual property: Powerhouse for innovation and economic growth. New York: International Chamber of Commerce.

INTERPOL (2014). Against organized crime: INTERPOL trafficking and counterfeiting casebookfor 2014. Lyon: INTERPOL.

Joyce, P. (2011). Policing: Development contemporary practice. London: Sage.

Kerns, R. W. (2016). The counterfeit food crisis in China: A systemic problem and possible solutions. North Carolina Journal of International Law \& Commercial Regulation, 41, 573-593. 
Klijn, E. H., Eshuis, J., \& Braun, E. (2012). The influence of stakeholder involvement on the effectiveness of place branding. Journal of Public Management Review, 14, 499-519.

Le Khac, N. N., Markos, S., O'neill, M., Brabazon, A., \& Kechadi, T. (2011). An investigation into data mining approaches for anti-money laundering. IACSIT, 2, 504-508.

Lewis, K. (2009). The fake and the fatal: The consequences of counterfeits. London: The Park Place Economist.

Mackrell, N. (1996). Economics consequences of money laundering in the $21^{\text {st }}$ century: Risks and countermeasures. Canberra: Australian Institute of Criminology.

Melzer, S. A. (2010). Counterfeit and contraband cigarette smuggling: opportunities, actors, and guardianship. Unpublished Doctor of Philosophy in Justice, Law and Society. Washington, DC: American University.

Miles, M. B, Huberman, A. M., \& Saldana, J. (2014). Qualitative data analysis: A methods source book. $3^{\text {rd }}$ edition. London: Sage.

Newburn, T. (2008). Handbook for policing. $2^{\text {nd }}$ edition. London: Willan.

OECD (1998). The economic impact of counterfeit. Paris: OECD.

Ramara, P. (2006). Enforcement of intellectual property rights in South Africa: The counterfeit goods Act. Pretoria: Spoor \& Fisher.

Reynald, D. M. (2011). Guarding against crime: Measuring guardianship within Routine Activity Theory. New York: Taylor Francis.

Rich, S. (2016). Corporate criminals and punishment theory. The Canadian Journal of Law \& Jurisprudence, 24(1), 97-118.

SAFACT (2009). Piracy in South Africa. Available from http://safact.co.za/piracy-facts. Accessed: 2018/11/19.

Siegel, L. J. (2010). Criminology: Theories, patterns and typologies. $10^{\text {th }}$ edition. Belmont: Wadsworth.

Sonmez, E. (2014). Cottage piracy, 3D printing and secondary trademark liability: Counterfeit luxury trademarks and DIY. Journal of San Francisco Law Review, 48, 757-792.

South African Institute of Intellectual Property law (2015). South Africa dumping ground for counterfeit. Johannesburg: SAIIPL.

South African Institute of Intellectual Property Law (2013). Anti-counterfeiting. Pretoria: SAIIPL.

South African Police Services (2018). National Crime statistics for the South African Police Services 2017/18. Pretoria: Government Printers.

South Africa (1999). White Paper on Safety and Security 1999-2004. Pretoria: Government Printer.

South Africa (1998). Prevention of Organised Crime Act 121 of 1998. Pretoria: Government Printer.

South Africa. (1996a). Constitution of the Republic of South Africa, Act No. 108 of 1996. Pretoria: Government Printer.

South Africa (1996b). National Crime Prevention Strategy. Pretoria: Government Printer.

South Africa (1995). South African Police Service Act (SAPS Act) 68 of 1995. Pretoria: Government Printer.

South Africa (1978). Copyright Act 98 of 1978. Pretoria: Government Printer.

Spilsbury, R. (2009). Counterfeit: Stopping fakes and forgeries. Los Angeles: Enslow.

Spink, J., Meyer, D., Park, H., \& Heinonem, J. (2013). Defining the types of counterfeiters, counterfeiting, and offender organisations. Crime Science: An Interdisciplinary Journal, 2(1), 1-10.

Spoor \& Fisher (2013). The Allure of Africa's rapidly Growing economy to counterfeiters. Pretoria: Spoor \& Fisher. 
G. Thenga - Policing of Goods Piracy in a Developing Country: A Case of South Africa

Staake, T., \& Fleisch, E. (2008). Countering trade: Illicit market insights best-practice strategies and management toolbox. Heidelberg: Springer.

Thenga, G. (2018). A critical analysis of the policing of counterfeit goods in South Africa. Unpublished thesis. PhD in Criminal Justice. University of South Africa, Pretoria.

Treadwell, J. (2011). From the car boot to booting it up? Ebay, online counterfeit crime and transformation of the criminal market. Criminology and Criminal Justice, 12(2), 175-191.

Tuba. D. (2012). Prosecuting money laundering the FATF way: An analysis of gaps and challenges in South African legislation from a comparative perspective. Acta Criminologica: Southern African Journal of Criminology. CRIMSA 2011 Conference Special Edition, (2): 103-122.

United Nations (2004). UN convention against transnational organized crime and the protocols thereto. New York: United Nations.

WIPO (2014). What is Intellectual Property? Available from http.www.wipo.int/edocs/ pubdocs/en/intproperty/450/wipo -pub-450. pdf. Accessed: 2018/07/20. 